\title{
THE MARKET STRUCTURE OF THE BANK, ITS PERFORMANCE, AND THE MACROPRUDENTIAL POLICY
}

\author{
Tumpak Silalahi' \\ Adler H.Manurung ${ }^{2}$ \\ Yuli Teguh Hidayat
}

\begin{abstract}
Recently, numerous Central Banks implement various macro-prudential policies to complement the existing monetary policy. This paper analyzes the impact of these policies along with the market structure, on the bank's performance. Using panel data analysis, this paper conclude that the reserve requirement ratio policy negatively affect the bank's performance (ROA). The empirical test shows the banking industry in Indonesia respond to the increase of reserve requirement by raising the Net Interest Margin to achieve their targeted operating profits. Secondly, this paper fail to find uniform conclusion across model variants about the effect of the policy rate on bank's performance. This also applies on the Loan to Value policy. Fourth, the market concentration has a more significant effect on banks' profitability as compared to market power. Fifth, the production index significantly affects the banking profitability. These findings implies a necessity for policy makers to review the financial market structure before formulating effective policy package to promote a healthy competition in the banking industry.
\end{abstract}

Keywords: Macro-prudential policy, banking structure, bank'sperformance.

JEL Classification: E52, E61, G21

1 Tumpak Silalahi is former economist at Center for Central Banking Research and Education and recently a senior resercher at Payment System Policy and Oversight Division at BankIndonesia. The views and opinions expressed in this paper are those of author and does not necessarily reflect the views of Bank Indonesia; email: silalahi@bi.go.id.

2 Adler H. Manurung is a lecturer at University of Indonesia;and Yuli Teguh Hidayat is member of University Padjadjaran, Bandung. 


\section{INTRODUCTION}

The objective of the macro-prudential instruments is to stabilize the financial systems. Thismacro-prudential policy may affect the profitability of the bank, and its effectiveness may subject to the market structure of the banking industry. This should be evident in emerging countries like Indonesia with their highly segmented banking market structure.

For the largest five Southeast Asian countries (ASEAN-5), Indonesia has the highest net interest margin (NIM), indicating the Indonesian banks are relatively less efficient than the other ASEAN countries. For Indonesia, this particular condition will potentially affect the effectiveness of the policies. The performance of Indonesian banks relative to other banks in the Southeast Asia are depicted on the Graph 1.

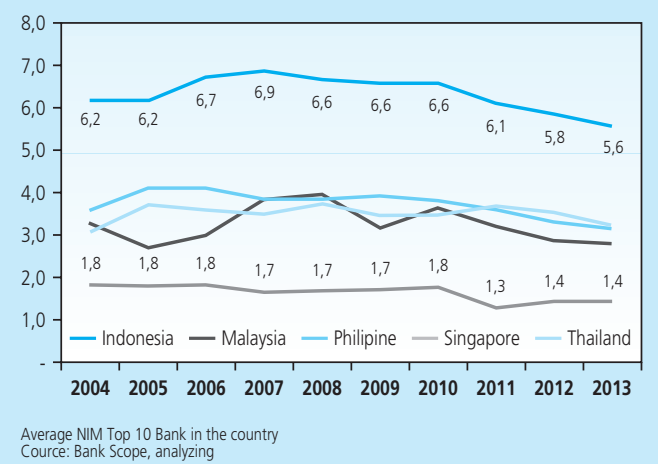

Graph 1.

Average Net Interest margin top 10 Bank's in ASEAN-5

The research on macro prudential regulation and its implementation is relatively new and in fact there is significant gap between the theoretical and the empirical research on this subject. This paper will review and analyze the impact of macro-prudential policies on the performance of the commercial banks in Indonesia. This paper will also identify if the market power or the market concentration is more prominent on the commercial bank profitability. Furthermore, this paper will analyze the interaction between the market power or the market concentration and the macro prudential policy in conjunction with the profitability of commercial banks in Indonesia.

Basically, this paper employ econometric model on quarterly commercial bank data from 2005 until 2014. We took the advantage of the longitudinal data and use the panel 
data estimation. We confront the estimated model with descriptive analysis and the existing studies.

The next section of this paper outlines the theory and related empirical literature. Section three discusses the methodology including the empirical model and data used on estimation. Section four provides the result of estimation and its analysis, while section five presents the conclusion, and will close this paper.

\section{THEORY}

Unlike the production of goods at micro level, the production of services in banking industry is more complicated. Xavier et al $(1998$, p.1) defines the operation of the bank as a financial institution that guarantees loans and accepts deposits from the public. While, Rose and Hudgins (2005) defines bank more comprehensively by the economic functions it serves and the services it offers to customers and as well as by the legal basis of it sexistence.

Several literatures explained the level of the banking productivity by diagnosing their balance sheets; this includes Xavier et.al (2008), Mankiw (1986), and Mishkin (2010). Simplified balance sheet of the bank is below,

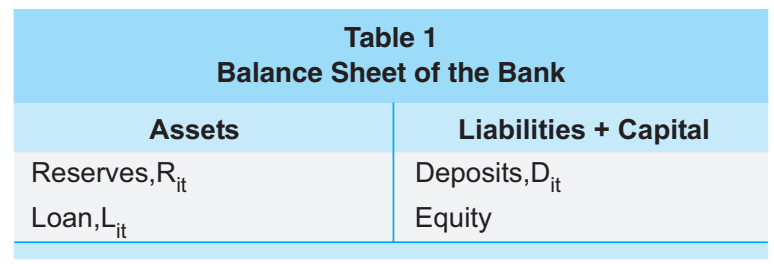

On the assets side, the reserve of the bank, $R_{i t}$ is highly related to the macroprudential policy. It is calculated as the difference between the volume of deposits received by the banks and the volume of loans disbursed $\left(D_{i t}-L_{i t}\right)$. Reserve of the bank can be classified into two types; statutory reserves (SR) and voluntary reserve placed in the interbank market $\left(M_{t}\right)$,

$$
R_{i t=} S R_{t}+M_{t}
$$

Monetary authorities generally require commercial banks to keep a portion of the public funds as statutory reserves (reserve requirement) and deposit it in the central bank either in cash or securities. The amount of the reserve requirement set by monetary authority affect the ability of banks to lend, which may affect the performance of the bank.

The simple Monti-Klein model is helpful in explaining the market structure, the conduct and the performance of the banking industry. Other theories in explaining the correlation between performance and concentration are Hypothesis of Structure Conduct Performance 
(SCP) and Hypothesis of Relative Market Power (RMP). The traditional SCP Hypothesis stated that the level of the bank profitability correlates to the level of market domination (or market concentration), since the market share will affect the bank's performance. Meanwhile, the RMP Hypothesis argues that the banks with more diversified products will have certain degree of market power, which helps to increase their profitability.

Smirlock (1985), examined the behavior of commercial banks in influencing the price that shows how much market power that empowered as an indicator of the level of competition in the market. The finding of the study was the level of competition in the emerging banking credit market is still quite high but cannot be categorized as a perfectly competitive market. Grigorian et.al (2002), concluded in their research on SCP, which is concentrated on bank structure impact on bank powers to set interest rates on loans and higher and lower interest rates on deposits.

According to Arreguy et.al (WP -13/167) even though the success of macro-prudential implementation is fruitful in terms of building resilience of the economy and a reduction of the probability of a crisis, and output losses in the event of a crisis, it will effect on the costs arise from an increase in the cost of intermediation and consequently output of the economy in the long-run. The cost of macro-prudential instruments should be different from one segment to the other segment of banks and it will affect their profits as well.

\section{METHODOLOGY}

\subsection{The Model Specification}

This paper uses panel data model to analyze role of macroprudential instruments and the market structure on the bank performance. We measurethe bank performance with net interest margin (NIM) and Return on Asset (ROA). There is a wide range of other external and internal factors determining the performance of the bank. This paper aims to fill the gap in research by incorporating the effect of macro-prudential instruments on bank performance in the presence of market concentration.

Following Fabozzi et.al (1986), Fama (1985) and James (1987), we formulate the following models:

\section{Model 1:}

$$
\operatorname{NIM}_{i t}=\propto_{0}+\beta_{1} \mathrm{SRR}_{i t}+\beta_{2} L T V D u m m y+\beta_{3} \text { GrowthLn }_{i t}+\beta_{4} G D P_{i t}+
$$

$$
\beta_{5} \text { Inflation }_{i t}+\varepsilon_{i t}
$$

where $i$ denotes bank $i$ and $t$ stands for year $t$, NIM is a Net Interest Margin measure the response of changing on macro prudential policy refer to reserve requirement and new regulation on LTV's. 


\section{Model 2:}

The equation model below is a reduced form, following Smirlock (1985), Molyneux and Forbes (1995) and Mirzar et.al. (2011) as follow:

$$
\begin{aligned}
& \pi_{i t=} c_{0}+a_{1} M S+a_{2} C R_{4}+K \\
& \mathrm{~K}=\mathrm{a}_{3} \mathrm{ASET}+\mathrm{a}_{4} \mathrm{CAR}+\mathrm{a}_{3} \mathrm{CIR}+\mathrm{a}_{4} \mathrm{NPL}+\mathrm{a}_{5} \mathrm{NIM}
\end{aligned}
$$

Where $\pi$ is measured by bank performance as a dependent variable in this econometric model, Market Structure (MS) and Market Concentration (CR) at the market level reflects the degree of collusive behavior that a firm did to extract higher profits.

\section{Model 3:}

The expanded version is developed by combining model Panel 1 and Model Panel 2 and it will used in this research as follows:

$$
\begin{gathered}
\pi_{i t}=\alpha_{0}+\beta_{1} \text { SRR }_{\text {it }}+\beta_{2} \text { DLTV }+\beta_{3} \text { GDP }_{\mathrm{t}}+\beta_{4} \text { Inflation }_{\mathrm{t}}+\beta_{5} \text { GrowthLn }_{\mathrm{it}} \\
+\mathrm{a}_{1} \mathrm{MS}+\mathrm{a}_{2} \text { CR4 }+\beta_{5} \text { SRRCR }_{\mathrm{it}}+\mathrm{K}+\varepsilon_{\mathrm{it}}
\end{gathered}
$$

where SRR is Real Reserve Requirement Ratio; DLTV is Loan to Value policy (in the form of dummy); GDP is the Growth Domestic Product; Infl is the inflation rate; MS is the market share power of the bank; $S R R C R$ is an interaction between the Reserve Requirement with the Market Structure; $C R$ is Concentration Share Power; Aset is Bank Asset; CAR is Capital Adequacy Ratio; $C I R$ is Cost to Income Ratio representing the efficiency; NPL is the Ratio of Non-Performing Loan; NIM is the Net Interest Margin; and Growth-Ln is the growth of Commercial Bank Loan.

We can specify the panel data model either Fixed Effect Model (FEM) or Random Effects Model (REM). The selection of the two methods is based on Hausman Test.

\subsection{Data and Variables}

As bank profitability is one of the indicators used in measuring the performance, it is necessary to investigate whether macro prudential policy and the level of market share (market power) of bank affect their profitability. There is still debate whether the market share (level of competition) lead to either market stability (stability concentration hypothesis) or market instability (fragility concentration hypothesis). When the latter dominates and the market instability reduces the efficiency and profitability of the banks, then the estimation result should be interpreted cautiously. 


\begin{tabular}{|c|c|c|c|c|}
\hline \multicolumn{5}{|c|}{$\begin{array}{c}\text { Table } 2 \\
\text { List of Variables }\end{array}$} \\
\hline No & Variables & Description & $\begin{array}{c}\text { Source of } \\
\text { Data }\end{array}$ & $\begin{array}{l}\text { Expected } \\
\text { Sign. }\end{array}$ \\
\hline 1 & $\begin{array}{l}\text { Real Reserve } \\
\text { Requirement }\end{array}$ & The change of Reserve Requirement Ratio. & $\begin{array}{c}\text { Bank } \\
\text { Indonesia(BI) }\end{array}$ & - \\
\hline 2 & LTV'S Dummy & $\begin{array}{l}\text { Event Study, reguation of Loan to Value =1 for } \\
\text { the period. Q-II } 2012 \text { since policy implementing } \\
\text { and= } 0 \text { for other period. }\end{array}$ & $\mathrm{BI}$ & - \\
\hline 3 & Market Power & Level of market share compare to bank industries & $\mathrm{BI}$ & + \\
\hline 4 & Concentration & Concentration of 4 firms to industry & $\mathrm{BI}$ & + \\
\hline 5 & $(\mathrm{CR} 4)$ & Total Asset of Bank & Bank Scope & $+/-$ \\
\hline $\begin{array}{l}6 \\
7\end{array}$ & $\begin{array}{l}\text { Bank } \\
\text { Asset(Asset) }\end{array}$ & $\begin{array}{l}\text { Capital of bank proxy by Capital Adequacy } \\
\text { Ratio(CAR) }\end{array}$ & $\mathrm{BI}$ & + \\
\hline & $\begin{array}{l}\text { Bank Capital } \\
\text { Bank Efficiency }\end{array}$ & Cost to Income Ratio notation: CIR & $\mathrm{BI}$ & - \\
\hline 8 & Credit Risk & Non-Performing Loan to Total Loan, Notation: NPL & $\mathrm{BI}$ & - \\
\hline 9 & $\begin{array}{l}\text { Net Interest } \\
\text { margin }\end{array}$ & Net Interest margin, notation: NIM & $\mathrm{BI}$ & + \\
\hline 10 & Loan Growth & Growth of bank loan & $\mathrm{BI}$ & + \\
\hline 11 & IP or GDP & Production Index or Economic Growth(GDP) & IFS & + \\
\hline 12 & Inflation & Inflation Index & IFS & + \\
\hline
\end{tabular}

The data are obtained from Bank Indonesia (Indonesian Banking Directory), Bank Scope and the data of International Financial Statistics (IFS). The accuracy of data can be trusted since the commercial banks have the obligation to submit data of the highest quality, where failure to comply could result in penalty charges.

By checking the data so the sample of bank choice becomes 98 banks out of 109 commercial bank figure out of $89.9 \%$ of total bank population. The descriptive statistic of the data gathered and variable used are presented in table 3.

Based on the table above, the variables can be classified into five groups, where Bank Performance as dependent variable is the first group. The second group is market structure of the bank industry that consists of market power and Market Concentration. Subsequently, macro prudential variable consists of reserve requirement and Loan to Value (LTV's). Internal bank characteristic consists of Capital Adequacy Ratio (CAR), Cost to Income Ratio (CIR), Nonperforming Loan (NPL'S), and Loan Growth as representative of bank indictor to provide a supply of loan to market. Lastly, macroeconomic indicator is representative of external factors that influence the banking performance. 


\begin{tabular}{|c|c|c|c|c|c|c|c|c|c|c|}
\hline \multicolumn{11}{|c|}{$\begin{array}{c}\text { Table } 3 \\
\text { Descriptive Statistic of Variable }\end{array}$} \\
\hline & Variables & Observation & Mean & Median & Maximum & Minimum & $\begin{array}{c}\text { Standard } \\
\text { Deviasi }\end{array}$ & Skewness & Kurtosis & Jarque-Bera \\
\hline \multirow{3}{*}{$\begin{array}{l}\text { Bank } \\
\text { Performance }\end{array}$} & ROA & 3136 & 3 & 3 & 18 & (6) & 2 & 1 & 6 & 1.236 \\
\hline & ROE & 3136 & 19 & 16 & 403 & (105) & 18 & 4 & 76 & 707.169 \\
\hline & NIM & 3136 & 6,44 & 5,77 & 20,15 & $(1,14)$ & 2,88 & 1,04 & 4,39 & 818 \\
\hline \multirow{6}{*}{$\begin{array}{l}\text { Market } \\
\text { Structure }\end{array}$} & MS Loan & 3136 & 0,02 & 0,00 & 0,35 & - & 0,05 & 3,99 & 20,01 & 46.132 \\
\hline & MS Funding & 3136 & 0,01 & 0,00 & 0,18 & - & 0,02 & 4,26 & 21,66 & 54.972 \\
\hline & MS_LOAN_X_NIM & 3136 & 0,12 & 0,03 & 3,21 & $(0,01)$ & 0,31 & 5,44 & 39,35 & 188.111 \\
\hline & MS_Funding_X_NIM & 3136 & 0,06 & 0,01 & 1,42 & $(0,01)$ & 0,16 & 4,66 & 27,21 & 87.986 \\
\hline & CR 4 Dana & 3136 & 0,49 & 0,49 & 0,52 & 0,39 & 0,02 & $(0,95)$ & 6,09 & 1.770 \\
\hline & CR 4 Loan & 3136 & 0,40 & 0,40 & 0,43 & 0,39 & 0,01 & 1,16 & 3,43 & 731 \\
\hline \multirow{6}{*}{$\begin{array}{l}\text { Makro } \\
\text { Prudential } \\
\text { Instruments }\end{array}$} & Efektive (Riil) Reserve & 3136 & 8,60 & 7,71 & 167,74 & - & 9,13 & 12,48 & 184,61 & 1.392 .231 \\
\hline & Requirement & & & & & & & & & \\
\hline & Rasio Statutory & 3136 & 5,84 & 5,00 & 8,00 & 5,00 & 1,35 & 0,97 & 1,95 & 640 \\
\hline & Log Statutory Reserve & 3136 & 14.838 & 7.446 & 48.834 & 2.284 & 15.285 & 1 & 3 & 867 \\
\hline & Dummy RR & 3136 & 0,62 & 1,00 & 1,00 & - & 0,48 & $(0,51)$ & 1,27 & 532 \\
\hline & RR & 3136 & 2.415 & 504 & 91.515 & - & 6.323 & 6 & 60 & 439.842 \\
\hline \multirow{6}{*}{$\begin{array}{l}\text { Bank } \\
\text { Characteristic }\end{array}$} & Average Total Asset & 3136 & 22.187 & 4.350 & 499.146 & - & 55.909 & 5 & 29 & 99.475 \\
\hline & CAR & 3136 & 23,96 & 18,80 & 678,18 & $(19,21)$ & 19,14 & 13,96 & 440,26 & 25.077 .174 \\
\hline & CIR & 3136 & 15,66 & 0,88 & 96,42 & 0,19 & 28,65 & 1,47 & 3,30 & 1.139 \\
\hline & NPL Gross Rasio & 3136 & 0,03 & 0,00 & 436.000 .000 & - & 0,09 & 18,33 & 593,31 & 45.562 .015 \\
\hline & Funding Growth & 3136 & 18.017.971 & 3.189 .293 & 63.40 & - & 47.358 .132 & 5 & 30 & 110.967 \\
\hline & Loan Growth & 3136 & 0,35 & 0,22 & 671.781 & (1) & 2 & 25 & 644 & 57.370 .784 \\
\hline \multirow[t]{4}{*}{ Macroeconomic } & Rill GDP & $\square 3136$ & 538.152 & 533.349 & 971.781 & 426.612 & 71.509 & 0 & 2 & 181 \\
\hline & Nominal GDP & 3136 & 1.346 .082 & 1.33 .842 & 2.119 .649 & 632.331 & 463.152 & 0 & 2 & 216 \\
\hline & PDB Deflator & 3136 & 10,91 & 10,03 & 21,10 & 2,73 & 4,72 & 0,52 & 2,5 & 173 \\
\hline & BI Rate & 3136 & 8,01 & 7,59 & 12,75 & 5,75 & 2,03 & 1,03 & 3,18 & 556 \\
\hline
\end{tabular}

\section{Hausman Test}

Hausman test is applied on panel data to choose the best modelunder null hypothesis of the Random effects Model is the best. The alternatives to the Hausman are the Chow Test and the LM Test.

The result suggests accepting the null hypothesis for Model 1, Model 2, and Model 3, and lead to the use of Random Effect Model. The use of REM also applies across the choice of dependent variable (ROA and ROE).

\section{RESULT AND ANALYSIS}

The performance of commercial banks highly depends on the internal and the external factors including monetary policy. Several empirical evidences indicate the goal of macroprudential 
policy to stabilize the macro economy does not align with the goal of commercial banks to maximize the shareholder value. In this section, we focus our analysis on how the market structure interacts with the macro prudential policy on affecting the banks' profitability.

\subsection{The effect of Macroprudential and market structure on ROA and ROE}

On the Model 1 the effect of macro-prudential policy is represented by the change in ratio of reserve requirement. Based on empirical evidence, it is observed that reserve requirement ratio has significant effect on ROA of Indonesian banks. The negative coefficient on reserve requirement means that for every $1 \%$ increase in reserve requirement, ROA decreases by $0.83 \%$. Negative sign coefficient of LTV policy shows that it has an inverse relationship with bank. Nonetheless, LTV policy has not shown big influence bank profitability since its implementation in 2012 as depicted in Model 1 that uses Fixed Effect model.

To policy makers, all these findings will assist them in simulating the effect of macro prudential policy on banks' profit and therefore determine the maximum increase in capital reserve requirement, which can be imposed on commercial banks to avoid contagion effect. This is important to maintain financial stability of Central Bank as a whole.

However for the banks with portfolio assets consisting marketable securities such as government bond or interbank call money, their strategy in anticipating change in the macro prudential policy is by changing the composition of deposits from expensive funding sources to less expensive ones such as saving and current deposit.

A new LTV, a macro prudential instrument, regulation that requires bank to apply a minimum 30\% down payment out of total financing on housing loan needs to be monitored closely as to prevent disastrous housing properties bubble.

Finding by Silalahi et.al (2012), shows that the short term growth of property prices is affected by the growth of bank lending, capital market index, interest rate, the GDP growth and the past growth in property prices from one and up three quarters lag. 


\begin{tabular}{|c|c|c|c|c|}
\hline \multicolumn{5}{|c|}{$\begin{array}{c}\text { Table } 4 \\
\text { The effect on Asset (ROA) }\end{array}$} \\
\hline \multicolumn{5}{|c|}{ THE EFFECT ON RETURN ON ASSET(ROA) } \\
\hline \multirow{2}{*}{ Dependent variable } & Model 1: ROA & Model 2: ROA & Model 3: ROA-ID & Model 4: ROA-ID \\
\hline & FE & RE & FE & RE \\
\hline \multicolumn{5}{|l|}{ I.Macro prudential variabel: } \\
\hline C & $\begin{array}{l}9,835945 * * * \\
0,194036\end{array}$ & $\begin{array}{c}8,785213^{* * *} \\
0,48\end{array}$ & $\begin{array}{r}-21,00665 * * * \\
0,656080\end{array}$ & $\begin{array}{r}-43,82804^{* * *} \\
0,910027\end{array}$ \\
\hline 1.Rasio Riil GWM & $\begin{array}{r}-0,768511 * * \\
(-0.222155)\end{array}$ & $\begin{array}{l}-2,162601 * * * \\
0,497570\end{array}$ & $\begin{array}{l}0,354598^{* * *} \\
0,229772\end{array}$ & $\begin{array}{l}0,283825 \\
0,140281\end{array}$ \\
\hline 2.Dummy LTV's & $\begin{array}{r}-0,010330 \\
(-0.024268) \\
\end{array}$ & $\begin{array}{l}0,013556 * * * \\
0,057346\end{array}$ & $\begin{array}{l}0,608491 * * * \\
0,024232\end{array}$ & $\begin{array}{l}0,633507 * * * \\
0,052609\end{array}$ \\
\hline 3.RIILGWM x MS Loan & $\begin{array}{l}0,000192 * \\
-0,00006\end{array}$ & $\begin{array}{l}0,000468 \\
0,000126\end{array}$ & & \\
\hline 4.RIILGWM x CR4 Loan & & & $\begin{array}{l}-0,828400 \text { *** } \\
0,020448\end{array}$ & $\begin{array}{r}-2,028867 \\
0,031607\end{array}$ \\
\hline \multicolumn{5}{|l|}{ II.Market structure } \\
\hline 1.Market Share Loan (MS) & $\begin{array}{r}-0,277227 \\
2,045893 \\
\end{array}$ & $\begin{array}{l}1,811488 \\
1,308463\end{array}$ & & \\
\hline 2.Market Concentration (CR4) & & & $\begin{array}{l}9,70 * * * \\
0,37\end{array}$ & $\begin{array}{r}133,9451 * * * \\
2,26380\end{array}$ \\
\hline 3.Interaction(MS loan*NIM) & $\begin{array}{l}0,143489 \\
0,006641\end{array}$ & $\begin{array}{l}-1,0740 \text { ** } \\
-0,7375\end{array}$ & & \\
\hline 4.Interaction( CR4*NIM) & & & $\begin{array}{l}-2,386925^{* * *} \\
0,050039\end{array}$ & $\begin{array}{l}-4,174324 \text { *** } \\
0,004957\end{array}$ \\
\hline \multicolumn{5}{|l|}{ III.Individual characteristic } \\
\hline 1.CAR & $\begin{array}{l}0,003079 * * * \\
0,000754\end{array}$ & $\begin{array}{l}0,001000 * * * \\
0,001054\end{array}$ & $\begin{array}{l}0,004556 * * * \\
0,002766\end{array}$ & $\begin{array}{l}0,001026 \\
0,001169\end{array}$ \\
\hline 2.Non Performing Loan & $\begin{array}{l}0,0629 \\
0,1410\end{array}$ & $\begin{array}{r}0,961473 \\
0,1927\end{array}$ & $\begin{array}{l}0,014278 * \\
0,060536\end{array}$ & $\begin{array}{l}0,6906611^{* *} \\
0,193623\end{array}$ \\
\hline 3.NIM & $\begin{array}{l}0,143489 * * * \\
0,006641\end{array}$ & $\begin{array}{r}0,206072 \\
0,0098\end{array}$ & $\begin{array}{l}0,01 \\
0,01\end{array}$ & $\begin{array}{l}-0,03^{* * *} \\
0,007\end{array}$ \\
\hline 4.Cost to income ratio(CIR) & $\begin{array}{r}-9,418208 * * * \\
0,124844\end{array}$ & $\begin{array}{c}-8,635575 * * * \\
0,182879\end{array}$ & $\begin{array}{l}0,076384 \text { ** } \\
0,165079\end{array}$ & $\begin{array}{l}0,295691 \\
0,098317\end{array}$ \\
\hline 5.Loan Growth & $\begin{array}{l}0,0063 \\
0,0213\end{array}$ & $\begin{array}{l}-0,366079 \text { *** } \\
0,130074\end{array}$ & $\begin{array}{l}-0,0706622^{* * *} \\
0,074090\end{array}$ & $\begin{array}{r}-0,413466 \text { ** } \\
0,167572\end{array}$ \\
\hline \multicolumn{5}{|l|}{ IV.Macroeconomic Factor } \\
\hline 1.Inflasi & $\begin{array}{r}-0,0025 \\
0,0034\end{array}$ & $\begin{array}{r}-0,015188 \\
0,009528\end{array}$ & $\begin{array}{l}-0,096710 * * * \\
0,003373\end{array}$ & $\begin{array}{l}-0,141559 * * * \\
0,002389\end{array}$ \\
\hline 2.Production incex(ip) & $\begin{array}{l}0,6280^{* * *} \\
0,0144\end{array}$ & $\begin{array}{r}-0,002838 \\
0,002730 \\
\end{array}$ & $\begin{array}{l}0,064699 * * * \\
0,001431\end{array}$ & $\begin{array}{l}0,147567 \\
0,001652\end{array}$ \\
\hline 3.policy rate (BI Rate) & $\begin{array}{r}-0,004622 \\
0,009687\end{array}$ & $\begin{array}{r}0,007961 \\
0,0227 \\
\end{array}$ & $\begin{array}{l}0,750118 \text { *** } \\
0,019788\end{array}$ & $\begin{array}{l}0,993645^{* * *} \\
0,010055\end{array}$ \\
\hline 4.AR(1) & $\begin{array}{l}0,627505 * * * \\
0,014345\end{array}$ & & $\begin{array}{l}0,716457^{* * *} \\
0,011862\end{array}$ & \\
\hline $1 \mathrm{R}$ - square & 0,965675 & 0,527125 & 0,735774 & 0,542160 \\
\hline 2 Durbin - Watson Stat & 1,945554 & 1,005939 & 2,155306 & 0,768049 \\
\hline
\end{tabular}




\subsection{The Effect of Market Structure on ROA and ROE}

The degree of market shares owns by each of the four most prominent banks had a greater role in influencing their profitability compared to extent of market power that each of them had. This finding is supported by variable CR4, which has positive coefficient. This finding is in line with research done by Mirzaei et.al. (2012), Perera et.al. (2013) and Smirlock, M (1985).

There are two hypotheses related to market structure, which are Structure Conduct Performance Hypothesis (SCP) or Relative Market Power Hypothesis (RMP). SCP hypothesis argues that market concentration has significant effect on performance of banks. However, Relative Market Power argues the capability of commercial bank to do product diversification will encourage efficiency and commercial banks can therefore achieve their optimal performance level by solely relying on their abilities to innovate on the services that they provide.

In emerging countries like Indonesia, empirical evidence shows that market concentration (CR4) has a more significant effect on banks' profitability as compared to market power (MS) This finding is supported by the $p$-value of market concentration, which proves CR4 to be significant at $5 \%$ significance level while MS is not. This finding is also supported by statistic of the four largest banks by asset and loan value and similar trend is also observed when the model is expanded to include eleven of the top banks. The above findings support the data that the aggregate profit of the top 10 banks in Indonesia makes up significant portion of total profit in the country's banking industry.

\begin{tabular}{|c|c|c|c|c|c|}
\hline \multicolumn{6}{|c|}{$\begin{array}{c}\text { Table } 5 \\
\text { The effect on Equity (ROE) }\end{array}$} \\
\hline \multicolumn{6}{|c|}{ The Effect on Return on Equity (ROE) } \\
\hline \multirow{2}{*}{ Model } & Model 1: ROE & Model 2: ROE & Model 3: ROE ID & Model 4: ROE ID & \\
\hline & Fixed Effect(FE) & Random Effect (RE) & FE & RE & \\
\hline \multicolumn{6}{|l|}{ Macro Prudential Policy: } \\
\hline Constanta & $\begin{array}{c}36,29520^{* * *} \\
4,037\end{array}$ & $\begin{array}{r}36,72779^{* * *} \\
6,380\end{array}$ & $\begin{array}{r}9.183^{* * *} \\
0.8054\end{array}$ & $\begin{array}{r}-0,94334 \\
0,056\end{array}$ & \\
\hline 1.Rasio Riil GWM & $\begin{array}{r}-0,20304 \\
3,813 \\
\end{array}$ & $\begin{array}{r}-0,09698 \\
8,715 \\
\end{array}$ & $\begin{array}{r}(3.586) \\
0.200192\end{array}$ & $\begin{array}{r}0,04403 \\
0,013\end{array}$ & \\
\hline 2.Dummy LTV's & $\begin{array}{c}9,10839 * * * \\
1,177\end{array}$ & $\begin{array}{r}9,59869 * * * \\
2,421\end{array}$ & $\begin{array}{l}0.009899 * * * \\
0.073053\end{array}$ & $\begin{array}{r}0,80869 \\
0,004 \\
\end{array}$ & \\
\hline 3.RIILGWM x MSLOAN & $\begin{array}{r}0,00073 \\
0,001\end{array}$ & $\begin{array}{r}0,00025 \\
0,002\end{array}$ & & & \\
\hline 4.RIILGWM x CR4LOAN & & & $\begin{array}{l}0,16 * * * \\
0,01\end{array}$ & $\begin{array}{r}0,18660 \\
0,002 \\
\end{array}$ & \\
\hline \multicolumn{6}{|l|}{ II.Market Structure } \\
\hline 1.Market Share Loan & $\begin{array}{r}84,16734 \\
55,792\end{array}$ & $\begin{array}{r}31,46544 \\
39,818\end{array}$ & & & \\
\hline 2.CR4-Loan & & & $\begin{array}{c}1.272 .699 \quad * * * \\
0,53\end{array}$ & $\begin{array}{c}0,15787 \quad * * \\
0,153\end{array}$ & \\
\hline 3.Interaksi MS Loan dengan NIM & $\begin{array}{r}-7,76397 \\
6,481\end{array}$ & $\begin{array}{r}2,15391 \\
6,035\end{array}$ & & & \\
\hline
\end{tabular}




\begin{tabular}{|c|c|c|c|c|c|}
\hline \multicolumn{6}{|c|}{ The Effect on Return on Equity (ROE) } \\
\hline \multirow{2}{*}{ Model } & \multirow{2}{*}{$\begin{array}{c}\text { Model 1: ROE } \\
\text { Fixed Effect(FE) }\end{array}$} & \multirow{2}{*}{$\begin{array}{c}\text { Model 2: ROE } \\
\text { Random Effect (RE) }\end{array}$} & Model 3: ROE ID & \multicolumn{2}{|l|}{ Model 4: ROE ID } \\
\hline & & & FE & RE & \\
\hline 4.Interaksi CR4 dengan NIM & & & $\begin{array}{r}-0,01 \\
0,00\end{array}$ & $\begin{array}{r}-0,00103 \\
0,001\end{array}$ & \\
\hline \multicolumn{6}{|l|}{ III.Karakteristik Individu } \\
\hline 1.CAR & $\begin{array}{l}0,004 \\
0,025\end{array}$ & $\begin{array}{l}-0,0441 \text { *** } \\
0,0147\end{array}$ & $\begin{array}{l}0,00 \text { * } \\
0,00\end{array}$ & $\begin{array}{r}0,00024 \text { ** } \\
0,000\end{array}$ & \\
\hline 2.NPLGRAS & $\begin{array}{l}9,195 * \\
5,203\end{array}$ & $\begin{array}{c}11,0418 * * \\
4,7405\end{array}$ & $\begin{array}{l}0,05 * * \\
0,03\end{array}$ & $\begin{array}{r}0,03299 \\
0,028\end{array}$ & \\
\hline 3.NIM & $\begin{array}{l}1,629 * * * \\
0,269\end{array}$ & $\begin{array}{c}1,34232 * * * \\
0,229\end{array}$ & $\begin{array}{l}1,38^{* * *} \\
0,02\end{array}$ & $\begin{array}{r}1,24854 \text { ** } \\
0,003\end{array}$ & $\star \star \star *$ \\
\hline 4.CIR_BOPO_ & $\begin{array}{l}0,178^{* * *} \\
0,051\end{array}$ & $\begin{array}{l}0,2093^{* * *} \\
0,0352\end{array}$ & $\begin{array}{l}0,03 \\
0,02\end{array}$ & $\begin{array}{r}0,01480 \text { * } \\
0,009\end{array}$ & \\
\hline 5.Growth Kredit Bank & $\begin{array}{r}-0,059 \\
0,190\end{array}$ & $\begin{array}{r}-0,0297 \\
0,2597\end{array}$ & $\begin{array}{r}-0,07 \quad * * * \\
0,02\end{array}$ & $\begin{array}{r}-0,06860 \text { ** } \\
0,021\end{array}$ & \\
\hline \multicolumn{6}{|l|}{ IV.Faktor Makroekonomi } \\
\hline 1.Inflasi & $\begin{array}{c}-0,07303 * \\
0,040\end{array}$ & $\begin{array}{c}0,21134 * \\
0,127\end{array}$ & $\begin{array}{l}0,011^{* * *} \\
0,00\end{array}$ & $\begin{array}{r}0,03164 \text { ** } \\
0,000\end{array}$ & \\
\hline 2.Indeks Produksi (-1) & $\begin{array}{c}0,02841 \text { ** } \\
0,014\end{array}$ & $\begin{array}{c}0,05336 \text { * } \\
0,031\end{array}$ & $\begin{array}{r}-0,03^{* * *} \\
0,00\end{array}$ & $\begin{array}{r}0,00097 \text { ** } \\
0,000\end{array}$ & \\
\hline 3.Sk Bunga Kebijakan (BI Rate) & $\begin{array}{c}0,35950 * \\
0,138\end{array}$ & $\begin{array}{c}-1,05294 * \\
0,464\end{array}$ & $\begin{array}{r}-0,15 * * * \\
0,00\end{array}$ & $\begin{array}{r}-0,12086 \text { ** } \\
0,001\end{array}$ & \\
\hline 4.ar(1) & $\begin{array}{c}0,79104^{* * *} \\
0,017\end{array}$ & & $\begin{array}{r}-0,23^{* * *} \\
0,02\end{array}$ & & \\
\hline 1.R - square & 0,75914 & 0,35936 & 0,80 & 0,77564 & \\
\hline 2.Durbin - Watson Stat & 2,12613 & 0,60097 & 2,29 & 2,64172 & \\
\hline
\end{tabular}

This finding is also in line with Lindgren et.al (1996, p.94) argues that the structure of the banking industry (including competition level) is essential for long term efficiency and soundness. A concentrated banking industry may enjoy economic rents; however is generally inefficient and unable to respond innovatively to charges in the economic environment. Lindgren et.al believed an open and competitive banking market exerts its own form of discipline against weak banks while encouraging well-managed banks.

In order to reduce the total number of operating banks by half, Indonesia's Financial Services Authority (OJK) is issuing a mandate merger of 10 small banks into one. As only small banks are involved in this plan, it will not affect the market concentration of Indonesia's banking industry.

The relationship between exogenous variable - macro prudential policy (reserve requirement and LTV ratio) with endogenous variable - bank's profitability is observed on the interaction between bank loan growth and Net Interest Margin (NIM). This argument is in line with Gray (2010) who argues that reserve requirement policy will affect bank interest rate spread. In theory, the direct effect of increasing of reserve requirement is decreasing banks' profitability opportunity from lending or buying marketable securities. 


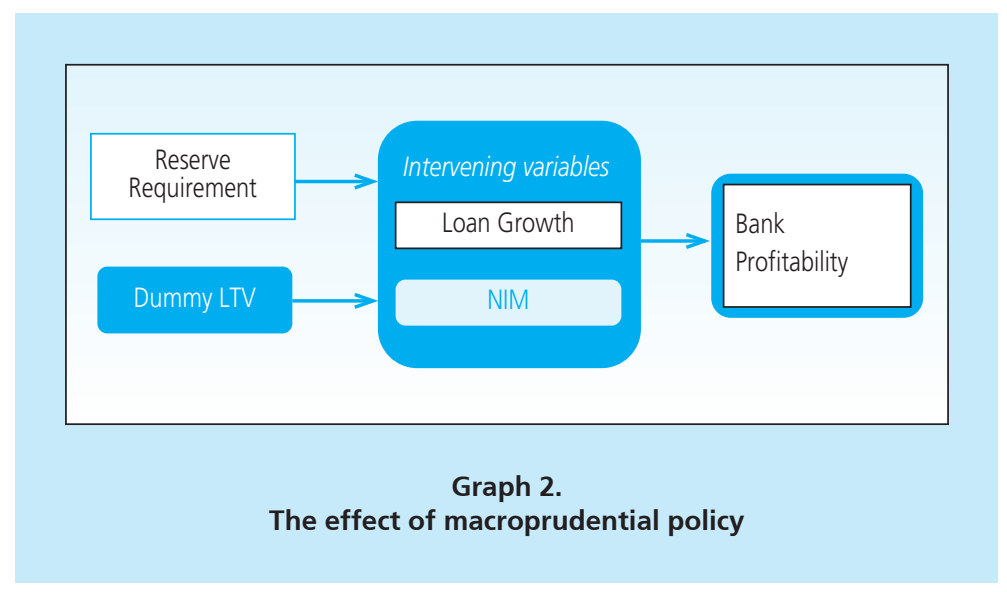

\subsection{The Effect of Macroeconomic Cycle on ROA AND ROE.}

Macroeconomic variable acts as a controlling variable on the effect of business cycle, which consists of inflation index with one quarter lag. Production index and policy rate on Model 3 and 4 have significant effect on the banking profitability, which conform to interpretation on the negative coefficient. Increase of policy rate will result in increase of commercial banks' interest rate and therefore cost of funding. However, under Model 1 and 2, it is observed that effect of policy rate on changes of the banks' profitability is not significant as commercial banks responds to change in policy rate by increasing their interest rate that causes NIM to be unaffected.

\subsection{The effect on the Return on Equity(ROE)}

By substituting ROE with ROA the model from 3.8 has a reduced form as follow:

$$
\begin{gathered}
\pi_{i t}=\alpha_{0}+\beta_{1} \text { SRR }_{i t}+\beta_{2} \text { DLTV }+\beta_{3} \text { IP }_{\mathrm{t}}+\beta_{4} \text { Inflasi }_{\mathrm{t}} \\
+\mathrm{a}_{1}{ }_{i t}+\mathrm{a}_{2} \text { CR } 4+\mathrm{K}+\varepsilon_{\mathrm{it}} .
\end{gathered}
$$

Reserve requirement influences significantly the profitability of banking while LTV policy's effect shows to be insignificant. This finding resonates with research done by Nier et.al. (2012), which found that when there was an increase in reserve requirement banks decided to increase their NIM in order to maintain ROA and ROE, which affected their profitability.

From banks' point of view, increase of reserve requirement is equivalent to extra tax burden that will be passed on to customers by increasing interest rate on loan or reducing of interest rate on deposits for customers. So the banking will respond to their clit by either increasing the rate loan or reducing deposit rate. This is done to maintain shareholder benefit, which is reflected by earning per share (EPS). 
The model has also included the effect of internal factor such as control variable. Internal characteristics are also important as they indicate whether the bank is a going concern and therefore this indicator is more favorable to banks with higher capital.

\subsection{Dynamic Panel Data Result}

The use of dynamic panel data is done by entering lag from the dependent variables as repressor in the regression process due to concern that using fixed effects and random effects approach produce a bias and inconsistent parameter (Verbeek 2008). Thus the method of moments approach or generalized method of moments or (GMM) proposed by Arellano and Bond (1991) is developed to neutralize bias characteristics of the pooled least squares estimators.

Furthermore in order to prove whether the implementation of macro-prudential policy is responded with banks increasing their NIM, equation 3.5 with dynamic panel model is used. In other words, crisis dummy variable that captures the macroeconomic conditions and banks' financial performance from the second quarter of 2008 to the third quarter of 2009 period is added to equation 3.5. This means for the specified period above the dummy variable will equal to one, which otherwise is equal to zero. The revised equation is as follow:

$$
\begin{gathered}
\text { NIM }_{\text {it }}=\alpha_{0}+\beta_{1} R_{\text {it }}+\beta_{2} \text { LTVDummy }+\beta_{3} \text { IP }_{\mathrm{t}}+\beta_{4} \text { Inflasi }_{\mathrm{t}} \\
+\beta_{5} \text { DKrisis }+\varepsilon_{\mathrm{it}}
\end{gathered}
$$

\begin{tabular}{|c|c|c|c|}
\hline \multicolumn{4}{|c|}{$\begin{array}{c}\text { Table } 6 \\
\text { The Effect on Net Interest Margin (Dynamic Panel) }\end{array}$} \\
\hline \multicolumn{2}{|r|}{ Net Interest Margin } & \multirow{2}{*}{\multicolumn{2}{|c|}{$\begin{array}{l}\text { Panel Generalized } \\
\text { Method } \\
\text { Moments (GMM) }\end{array}$}} \\
\hline No. & Dependent Variable & & \\
\hline \multirow[t]{2}{*}{1} & \multirow[t]{2}{*}{$\operatorname{NIM}(-1)$} & 0,76 & \multirow[t]{2}{*}{$* * *$} \\
\hline & & 0,03 & \\
\hline \multirow[t]{2}{*}{2} & \multirow[t]{2}{*}{ RIIL_GWM_RP } & $-7,20$ & \multirow[t]{2}{*}{ *** } \\
\hline & & 1,07 & \\
\hline \multirow[t]{2}{*}{3} & \multirow[t]{2}{*}{ DUMMY_LTV } & $-0,14$ & \multirow[t]{2}{*}{ ** } \\
\hline & & 0,04 & \\
\hline \multirow[t]{2}{*}{4} & \multirow[t]{2}{*}{ IP } & 0,01 & \multirow[t]{2}{*}{$* * *$} \\
\hline & & 0,00 & \\
\hline \multirow[t]{2}{*}{5} & \multirow[t]{2}{*}{ Inflasi } & 0,04 & \multirow[t]{2}{*}{$* * *$} \\
\hline & & 0,00 & \\
\hline \multirow[t]{3}{*}{6} & \multirow[t]{2}{*}{ Dkrisis } & $-0,24$ & \multirow[t]{2}{*}{ ** } \\
\hline & & 0,05 & \\
\hline & J-statistic & 65,79 & \\
\hline
\end{tabular}

The results of the tests in the table below indicate the following: 
Sargan test on the instrument yields $p$-value of 0.7706 that indicates that the null hypothesis is rejected and therefore the instrument used is proper.As shown in table above NIM (-1) has a coefficient 0.76 , which is below 1 indicates that the influence of NIM with one quarter lag is not that significant. While the influence of the change of Reserve Requirement and LTV has a negative sign that corresponds to the expectation of the sign test. Similarly, negative coefficient on the crisis dummy variable, shows that NIM, a proxy of bank's profitability, is affected during the specified period above. IP reflects the economy's growth, in which its positive coefficient can be interpreted as there IP for each $1 \%$ increment on economic growth, there is $0.01 \%$ increase in NIM.

Macroeconomic factors in this study are represented by the level of inflation, the production Index and policy rate (BI Rate). As suggested by the sign of the policy rate coefficient, the variable is negative related to ROA of banks. One possible explanation is bank responds to increase interest rates, which translates to higher cost of funds for banks taking out loan. Policy rate however has a fairly low coefficient value. The small change of ROA for every 25 basis points change in policy rate could possibly be attributed to the returns that banks earn on their portfolio of Bank Indonesia Certificates (SBI) that is less risky compared to other productive assets like loans given to other banks.

The use of external variables in this research is intended to be a controlling variable that captures changes to the macro-economic cycle, which in theory influences banks' behavior that affect their profitability. In theory, on the booming economic conditions or expansion stage of the economic cycle, bankstend to experience higher level of profitability as they are likely to increase the channeling of credit. On the other hand, during recession, banks tend to lower credit supply in line with falling credit demand by borrowers therefore banking profitability levels tend to decline.

\section{CONCLUSION}

As can be shown from Model 1 and 2 in the econonometric model, Reserve requirement ratio negatively affect the bank's performance (ROA); a 1\% increase in reserve requirement will reduce the ROA by $0.83 \%$. Meaning that, the role of reserve requirement instruments as one of the macroprudential instrument is effective on stabilizing the financial bubble.

LTV policy also negatively affect the bank profitability. However for the banks with portfolio assets consisting marketable securities such as government bond or interbank call money, their strategy in anticipating change in the macro prudential policy is by changing the composition of deposits from expensive funding sources to less expensive ones such as saving and current deposit.

The market concentration (CR4) has a more significant effect on banks' profitability as compared to market power (MS) This finding is supported by the $p$-value of market concentration, 
which proves CR4 to be significant at $5 \%$ significance level while MS is not. This finding is also supported by statistic of the four largest banks by asset and loan value and similar trend is also observed when the model is expanded to include eleven of the top banks.

In the Model 3 and 4, Production index and policy rate on Model 3 and 4 have significant effect on the banking profitability, which conform to interpretation on the negative coefficient. Increase of policy rate will result in increase of commercial banks' interest rate and therefore cost of funding. However, under Model 1 and 2, it is observed that effect of policy rate on changes of the banks' profitability is not significant as commercial banks responds to change in policy rate by increasing their interest rate that causes NIM to be unaffected.

LTV policy's effect shows to be insignificant. From banks' point of view, increase of reserve requirement is equivalent to extra tax burden that will be passed on to customers by increasing interest rate on loan or reducing of interest rate on deposits for customers. So the banking will respond to their clit by either increasing the rate loan or reducing deposit rate. This is done to maintain shareholder benefit, which is reflected by earning per share (EPS).

This paper provides some conclusions and policy recommendations; Firstly, the Central Banks need to understand the determinant of banks' performance. Secondly, investigating the impact of macroprudential policies should take into account the market share aspect. Failure to understand the the interaction between macro-prudential instruments and market power might pose a risk to financial stability. These conclusions have policy implications on designing macroprudential instruments. For this reason, good coordination and joint research between the monetary and the fiscal authority is a necessity to provide financial stability.

Macro-Prudential Policy which consists of a compulsory reserve requirement (GWM) and LTV's is aimed at achieving the objectives of macroeconomic stability and the stability of the financial system. In order to formulate effective policy and to promote healthy competition in the banking industry, it is necessary for regulator and policy maker to review the financial market structure.In oligopoly market, empirical test results have shown that the banking industry in Indonesia responded to increase in reserve requirement by raising the Net Interest Margin as to achieve targeted operating profits. 


\section{REFERENCE}

Arreguyet.all (IMF WP -13/167), Implementing Macroprudential, IMF.

Fabozzi, F. J., \& T.B, T. 1986. State Taxes and Reserve Requirements as Major Determinants of Yield Spreads Among Money Market Instruments. Journal of Financial and Quantitative Analysis , 21(4):427-36.

GrigoriandanManole (2002), Determinant of Commercial Bank Performance in Transtion Economies: An Application of Data Envelopment Analysisis, The World bank, WP 2850.

Smirlock, M. 1985. "Evidence of the (Non)-Relationship between Concentration and Probability in Banking", Journal of Money, Credit and Banking, vol.17, no.1,pp.69-83.

Verbeek, M. 2008.A Guide to Modern Econometrics, John Wiley \& Sons, Ltd.

Xavier, Freixas and Jean Charles Rochet 2008, Microeconomic of Banking,2nd Edition, The MIT Pres Cambridge, Massachusetts London, England. 